DOI https://doi.org/10.18551/rjoas.2017-01.02

\title{
GREEN BANKING: BANGLADESH PERSPECTIVE AND INTERNATIONAL EXPERIENCES
}

\author{
Khan Touhidul Alam, Naim Md. Julker* \\ Bangladesh University of Professionals, Bangladesh
}

Islam Rashedul

Marine and Coastal Resources Institute, Prince of Songkla University, Thailand

\author{
Begum Khadiza \\ Fareast Finance and Investment Ltd, Bangladesh \\ *E-mail: naim.jnu.bb@gmail.com
}

\begin{abstract}
Climate change is the most complicated issue the world is facing. Across the globe there have been continuous endeavors to measure and mitigate the risk of climate change caused by human activity. Many countries the world over have made commitments necessary to mitigate climate change. Although banks are considered environment friendly and do not impact the environment greatly through their own 'internal' operations, the 'external' impact on the environment through their customers activities is substantial. The banking sector is one of the major sources of financing industrial projects such as steel, paper, cement, chemicals, fertilizers, power, textiles, etc., which cause maximum carbon emission. Therefore, the banking sector can play an intermediary role between economic development and environmental protection, for promoting environmentally sustainable and socially responsible investment. 'Green banking' refers to the banking business conducted in such areas and in such a manner that helps the overall reduction of external carbon emission and internal carbon footprint. To aid the reduction of external carbon emission, banks should finance green technology and pollution reducing projects. Although, banking is never considered a polluting industry, the present scale of banking operations have considerably increased the carbon footprint of banks due to their massive use of energy ( e.g., lighting, air conditioning, electronic/electrical equipments, IT, etc), high paper wastage, lack of green buildings, etc. Therefore, banks should adopt technology, process and products which result in substantial reduction of their carbon footprint as well as develop a sustainable business.
\end{abstract}

\section{KEY WORDS}

Green banking, climate change, sustainable, developing countries, Bangladesh.

Bangladesh can lessen significant amount of carbon emission and conserve its forests and environment through adopting energy efficient clean technology in brick kilns. However, there is hardly any research work on securing environment with special focus on energy saving automated brickfield role in Bangladesh. Rapid urbanization and industrialization help improve the live hood of the beings simultaneously, it create strain on natural resource such as energy water and food supplies our plants ability to meet the growing demand of urbanities may be depleted if we don't become environment conscious .climate change has become a global concern as it direct impact on biodiversity, agriculture forestry dry land water resource and human health. Environmentalism is a broad philosophy and social movement. Regarding concern for environmental concern conservation and improvement of the state of the environmental .Environmentalism and environmental concern are often represented by color of "green "Global warming also called Green house effect is a global issue that calls for a global response. The warming effect of certain man-made gas emission such as carbon-dioxide methane, nitrous oxide and hydro-fluro carbon is found responsible for distortion in climate changes. The rapid to change in climate will probably be too great 
allow many eco systems to suitably adapt, since the changes have direct impact on bio diversity, agriculture, forestry, dry land, water resources and human health. However, there is general lack of adequate awareness on the above issues and -hence there is urgent need to promote certain urgent measures for sustainable development and corporate social responsibility.

\section{LITERATURE REVIEW}

Green Banking is the new form of banking toward to protect environment activities and sustainable development. The banking sector is an intermediary role between economic development and environment protection through their activities. This concept was formally developed in some countries in 2003 with the vision to protect the environment. Bangladesh Bank is adopted by financial institutions, especially banking, for determining, assessing and managing environmental and social risk in projects. Now, the concept appeared in many countries' policies and has an impaction to both of economic and environment. World Bank also had the publication Environmental \& Social (E\&S) norms for financial institutions including commercial banks, investment funds and leasing companies, to define their role on the environmental impact. These norms provided for financial institution an overview about environmental and social risks or opportunities. Those also gave an Environmental and Social Management System (ESMS) for the institution to outline the way to protect environment. The principles are including:

- E\&S Policy and Objective;

- Transaction Screening and Risk Categorization;

- E\&S Due Diligence (ESĐ) and Corrective Action Plans;

- E\&S Covenants;

- Monitoring E\&S Performance;

- Supporting Tool, Systems and Organizations;

- Roles, Responsibilities and Capacity Building.

\section{METHODOLOGY OF RESEARCH}

This paper reviews the literature on the previous researches on green banking and green bank model. Case studies research of developing and developed countries are used to withdraw the best practices in green banking. Some in-depth interviews with bank leaders in Bangladesh are also conducted to obtain the ideas and personal perspectives on difficulties and opportunities for Bangladesh bank when developing green banking activities. These will help the authors to have an independent analysis point of view and arguments in the papers.

\section{INTERNATIONAL EXPERIENCES AND BANGLADESH PERSPECTIVES}

International Experiences. In many countries around the world, Green Bank is a new concept has been known in recent years, particularly for developing countries including Bangladesh, because the requirements of environmental protection are trade-offs to achieve growth, economic development. However, after the global financial crisis in 2008, all countries in the world have to recognize the ways of organizing and operating model in its financial system, including banks. The issue of sustainable development, responsible business and corporate social responsibility, ethics and the environment are reviewed under a higher importance. Hence, the Green Bank emerged as a role model for banking in the future, is the foundation for the direction to a green economy for sustainable development. In 2002, the International Finance Corporation (IFC) and 9 international banking conferences in London discussed the responsibility of banks to the finance development and construction of a decision to implement the standard for accountability the environment, society based on the standards of IFC. Equator Principles (EPFIs) for funding the project was officially 
launched in 2003 and now has 77 participating financial institutions. The standards will play an important role in the classification and ranking of green bank today. (Equator principles)

United States. In March 2009, the US introduced a Green Bank Act with aim of establishing a green bank under the ownership of the US government. The initial decision was to minimize the paper use in banking works. One is in-house green banking; another is practice by the bankers in their business area. Other activities was including creating clean and hygienic banking environment, green building, reforestation, online banking, waste management, installation of solar panel on the rooftop of the bank and using high mileage vehicles, reducing sound pollution, using webcam for video conferencing instead of physical meetings, online statements, emailing documents are

included in the in-house green banking. On the other hand, the banking sector supported to the green projects like Biogas Plant, Solar/Renewable Energy Plant, Biofertilizer Plant, Effluent Treatment Plant (ETP), Projects having ETP etc. A typical example of a green bank is in the United States. In the past of difficulties, when U.S. banks impose high fees and creates bad debt, a type of bank is emerging. It is the banks having a social conscience and applying principles of sustainable development and responsible for the business model and its products. An excellent model of the new wave of green bank is the launch of Green Choice Bank in Chicago area; Green Bank in Dallas (Schultz, 2011) The United States also develop standards to evaluate and rank the level of "green" of the bank, published periodically by the Insurance Corporation Federal Deposit (FDIC). America is also the first nation regulates on environmental responsibilities of stakeholders, including bank loans in the United States must be governed by laws Reimbursement Act, Comprehensive Environmental (CERCLA) in 1980. In a study of the potential role of green bank in the state of California , Juhnke C., et al. (2012) evaluated the potential impact of a Green Bank in energy efficiency and distributed generation , based on 6 criteria: (1) the number of additional projects are funded, (2) cost-effectiveness of the bank, (3) increase the benefits provided by the bank, (4) the feasibility the bank's management, (5) the ease of integration with existing programs of the government and (6) the political viability. Thereby, studies have demonstrated the presence of Green Bank has helped to increase the flow of capital costs to compete effectively, thus helping the state achieve clean energy and help reduce many of the current problems are plaguing this market. The study "Sustainable Bank" of Imeson M., and Sim A., (2010) showed a close relationship between banks and factors: economic, social and environmental. Thereby, the study shows that a bank for sustainable development, the investor decided to look at the big picture and act in a way that benefits the consumer, economy, society and environment.

India. In India, the application of green programs for the environment and the community has been deployed for more than 2 decades, mainly loan programs for women, grant credits for economic development projects local. Since July 2010, the State Bank of India (SBI) has implemented the "green channel Counter (GCC)" and "banks do not line up" in more than 5,000 branches throughout India, as a step towards innovation "green bank" paperless transactions to send, withdraw and transfer money, pay and abroad. (Sahoo \& Nayak, 2008) Some of public sector banks and private sector banks were also adopted green banking policies and provided green products and services. Case study of ICICl Bank Ltd in India is a particular example about adopted "Go Green" initiative included (Note 3):

- Green Products and Services: This innovation was including (i) Instabanking; (ii) Vehicle Finance and (iii) Home Finance;

- Green Engagements;

- Green Communications: The institution provided to their customer for online bill payment, online funds transfer and subscription to e-statements that were promoted paperless and commute free;

- Green Partners: Beside the traditional customers, $\mathrm{ICICl}$ was also looking forward for green organizations and NGO.

However, the banking sector still was small role to positive impact environment in India. None of banks has adopted equator principle even for the sake records (Sahoo \& Nayak, 2008). Research "Green Bank in India" by P. Nayak, (2008) demonstrated the importance of 
Green Bank, and recommends methods and political initiatives that are feasible to promote development green banking in India.

China. China has also implemented the "Green Credit Policy" in 2007, to encourage Chinese banks to grant credit for projects less polluting, environmentally friendly and energy use renewable energy. However, China has spent nearly 5 years since the policy issued until construction is detailed guidelines on implementing this policy (February 2012) and its implementation did not achieve as expected to evaluate the system due to lack of reliable data on pollution to help the banks financing the project classification. (Zhang, Yang \& Bi, 2011).

United Kingdom. Research on the Green Investment Bank (Green Investment Bank) by Vivid Economics and McKinsey (2011) have emphasized the role of the GIB which was established in 2010 by agreement of the UK government coalition finishing policy framework and the financial support necessary to address the failures of the free market, risk aversion, high transaction costs and lack of funds. According to this study, GIB could help expand the potential investors, improve the economic efficiency of the project and share information to reduce risk, namely, the evidence of the failure of market and opportunities GIB intervention as follows: (1) Sea wind energy: GIB help increase new investors, financial support to thereby increase the amount of renewable electricity as well as reducing the carbon footprint environment, (2) Use external power source of UK is an effective option for reducing carbon emissions in the UK territory, strengthen energy security and long -term competitiveness of the industry, the time, GIB also helps mobilize funding for the project and reduce carbon emissions into the environment, (3) GIB also supports waste processing industry to minimize the landfill, generate heat renewable energy and carbon emissions. The analysis of Vivid Economics and McKinsey (2011) showed that in all three cases, the intervention of the GIB is more efficient and fair, in addition to the current policy. GIB's intervention helped to mobilize funds from equity market, debt markets and enable pricing of risk in financial markets through enhancing transparency and widened investment flows into sustainable development projects.

Greece. Angelos Papastergiou (2001) examines the sustainable development problem of banks in Greece. This paper shows the positive developments in sustainable banking. Some of banks could ignore the economic characteristics of customers if these projects were considered the beneficial effects on the environment. On the other hand, it is frequently asserted that small banks signed of the Equator Principles, which was one of the most important standards for responsible financing, had been under the umbrella of larger banks. Only the largest Greek banks provided the detail of environmental activities while the other banks were not. It is general accepted that the environmental performance of Greek bank was bias, it was depend on banks' structure and dimension.

Bangladesh. Maruf's study (2010) showed that in Bangladesh only public banks and foreign banks are operating guidance for green banking and financing some projects environmental friendly. Commercial banks are encouraged to sponsor the wastewater treatment plant in the industrial park; the project uses solar energy; biogas. This study also made recommendations that the banking green in Bangladesh should be catalyzed and supported by investment and public spending, and improving policies and government regulations. Raad Mozib Lalon (2015) listed the Green Banking Policy in Bangladesh concerned based on three phase through time of framework. The policies were encouraged banking sector to avoid as much as possible paper works and relying on electronic transactions for processing of in-house activities. Moreover, it also created brand image and create awareness amongst the stakeholders about the environment as well as environmental friendly business practices. On the other hand, this policy was also building a sanction loans to environmentally harmful projects so that make sure to:

- Phase I concerned to develop the awareness and show general commitment on environment through banks' performance including 9 policies: (1) Policy Formulation and Governance; (2) Incorporation of Environmental Risk in Core Risk Management; (3) Initiating In-house Environment Management; (4) Introducing Green Financing; (5) Creation of Climate Risk Fund; (6) Introducing Green Marketing; (7) Online Banking; 
(8) Supporting Employee Training Consumer Awareness and Green; (9) Reporting Green Banking Practice.

- Phrase II was based on 7 components: (1) Sector Specific Environmental policies; (2) Green Strategic Planning; (3) Setting up Green Branches; (4) Improved In-house Environment Management; (5) Formulation of Bank Specific Environment Risk Management Plan and Guideline; (6) Rigorous Programs to Educate Clients; (7) Disclosure and Reporting of Green Banking Activities.

- Phrase III was processing 1-year after Phrase II. It was based on a system of Environmental Management to address the whole eco-system through environment friendly initiatives and introducing innovative products including two parts: (1) Designing and Introducing Innovative Product and (2) reporting in Standard Format with External Verification.

\section{RECOMMENDATION FOR BANGLADESH PERSPECTIVE}

Green Bank in Bangladesh. In developing countries, benefits of green banking can be shown more directly such as avoids paper work:- Until a few years ago, most traditional banks did not practice green banking or actively seek investment opportunities in environmentally-friendly sectors or businesses. Only recently these strategies become more prevalent, not only among smaller alternative and cooperative banks, but also among diversified financial service providers, asset management firms and insurance companies. Although these companies may differ with regard to their stated motivations for increasing green products and services (e.g. to enhance long-term growth prospects, or sustainability principles on which a firm is based), the growth, variation and innovation behind such developments indicate that we are in the midst of a promising drive towards integrating green financial products into mainstream banking. Bank products and services can also reflect a green banking commitment and in figure 1 shown the diagram.

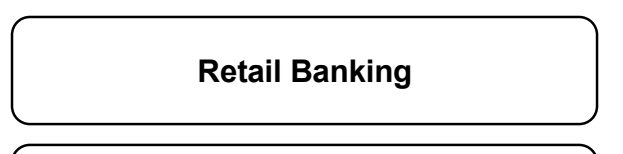

Asset Management
Corporate \& Investment Banking

\section{Insurance}

Figure 1 - The classification of banking sectors according to their product and service review

Banks is well aware of the environmental degradation situation as mentioned above and has already given time to time directions to all scheduled banks. Commercial Banks are now required to ensure necessary measures to protect environmental pollution while financing a new project or providing working capital to the existing enterprises. Banks have been advised to facilitate their clients with utmost care in opening Letter of Credit (L/C) for installation of Effluent Treatment Plant (ETP) in the industrial units. Banks have been advised to finance in Solar Energy, Bio-gas, ETP and Hybrid Hoffman Kiln (HHK) in brick field under refinance program of BB. A comprehensive guideline on Corporate Social Responsibility (CSR) has been issued where banks have been asked to concentrate hard on linking CSR at their highest corporate level for ingraining environmentally and socially responsible practices and engaging with borrowers in scrutiny of the environmental and social impacts. Banks have been brought under the purview of E-commerce with a view to providing the customers with online-banking facilities covering payments of utility bills, money transfer and transactions in local currency through internet as well. Considering the adverse effects of Climate Change, banks have been advised to be cautious about the adverse impact of natural calamities and encourage the farmers to cultivate salinity resistant crops in the salty areas, water resistant crops in the water locked and flood prone areas, drought resistant crops in the drought prone areas, using surface water instead of underground water for irrigation and also using organic fertilizer, insecticides by natural means instead of using chemical fertilizer and 
pesticides.

The term green banking generally refers to banking practice that foster environmentally responsible financing practice and environmentally sustainable internal process minimizing GHG emissions.

Green Banking has two approach, these are:

- Green Banking focuses on green transformation of internal operations of all banks;

- All Banks should adopt environmental risk of project before making financing decision and in particular supporting and fostering growth of up-coming green initiatives and projects.

Recommendation for Bangladesh Market:

As of now, environmentally sustainable units in Bangladesh are not implemented to a fuller extent because of the present set up of the companies. According to the environmental regulation of green banking in Bangladesh, industries are supposed to have an eco-friendly set up but the present setup cannot be changed instantaneously as it would create a financial burden for the industries itself.

According to the legal frame work of green banking, the Polluting industries either have to close down or have to make necessary investment to comply with the standard. In this process these industries will lose their competitiveness in the international market, which would directly affect our economy and the banking sector.

Despite of all the odds banks are still trying to do their part in sustainable development by using solar powered ATM"s, Online and mobile banking initiatives etc, thus creating a path towards green planet.

\section{CONCLUSION}

In a rapidly changing market economy where globalization of markets has intensified the competition, the industries and firms are vulnerable to stringent public policies, severe law suits or consumer boycotts. This would affect the banks and financial institutions to recover their return from investment. Thus, the banks should play a pro-active role to take environmental and ecological aspects as part of their lending principle which would force industries to go for mandated investment for environmental management, use of appropriate technologies and management systems. Green Banking if implemented sincerely will act as an effective for the polluting industries that give a pass by to the other institutional regulatory mechanisms. There has not been much initiative in this regard by the banks and other financial institutions in Bangladesh though they play an active role in India's emerging economy. The banking and financial sector should be made to work for sustainable development. As far as green banking in concerned, Bangladesh's banks and financial institutions are running behind time.

\section{REFERENCES}

1. Aliyu, A., Younus, S., \& Tasmin, R. (2012). An exploratory study on adoption of electronic banking: Underlying consumer behavior and critical success factors, Case of Nigeria. Business and Management Review, 2(1), 1-6.

2. Bihari, S. (2011). Green banking-towards socially responsible banking in India. International Journal of Business Insights and Transformation, 4(1), 84-87.

3. Bowersox, D.J., \& David, C.C. (1996). Logistical management: The integrated supply chain process.

4. McGraw-Hill Series in Marketing, New York: The McGraw-Hill Companies.

5. Bucklin, L., \& Sengupta, S. (1993). Organizing successful co-marketing alliances. Journal of Marketing, 57, 32-46. http://dx.doi.org/10.2307/1252025

6. Chain management (n. d.). Purchasing, 120(1), 110-113.

7. Cooper, M. C., Ellram, L. M., Gardner, J., \& Hanks, A. (1997). Meshing multiple alliances. Journal of Business Logistics, 18(1), 67-91. 
8. Economist Intelligence Unit \& Kpmg Professional Services. (2000). The e-business Value Chain: Winning strategies in seven global industries. The Economist. Equator principles. Retrieved from http://www.equator-principles.com

9. Furst, K., Lang, W., \& Nolle, D. (2002). Internet Banking. Journal of Financial Services Research, 22, 95-117. http://dx.doi.org/10.1023/A:1016012703620

10. Goldstein, D. (2000). Financial sector reform and sustainable development: The case of Costa Rica.

11. Lienviet Postbank. (2012). Retrieved from http://lienvietpostbank.com.vn

12. SOGESID Spa. The evolution of the Sustainable Development concept. Retrieved from http://www.sogesid.it/english_site/Sustainable_Development.html

13. Ullah, M. M. (2010). Green Banking in Bangladesh-A Comparative Analysis. Retrieved February 20, 2013, from http://www.wbiconpro.com/610-Maruf.pdf

14. UN ESCAP. (20120. Green Finance. Retrieved from http://www.unescap.org

15. Yang, J., \& Ahmed, K. T. (2009). Recent trends and developments in e-banking in an underdeveloped nation-an empirical study. Int. J. Electronic Finance, 3(2), 115-132. http://dx.doi.org/10.1504/IJEF.2009.026355

16. Yang, J., Cheng, L., \& Luo, X. (2009). A comparative study on e-banking services between China and USA. Int.

17. J. Electronic Finance. http://dx.doi.org/10.1504/IJEF.2009.027848

18. Zhang, B., Yang, Y., \& Bi, J. (2011). Tracking the implementation of green credit policy in China: Top-down perspective and bottom-up reform. Journal of environmental management, 92(4), 1321-1327. http://dx.doi.org/10.1016/j.jenvman.2010.12.019

19. Zhao, A. L. et al. (2008). Perceived risk and Chinese consumers' internet banking service adoption. International Journal of Bank Marketing, 26(7), 505-525. 